Article

\title{
Franciscan Prophets and the Inquisition (1226-1326)
}

\author{
C. Colt Anderson
}

Graduate School of Religion and Religious Education, Fordham University, 441 East Fordham Rd, Bronx, NY 10458, USA; coltanderson@fordham.edu

Received: 20 January 2018; Accepted: 15 March 2018; Published: 3 April 2018

Abstract: This paper examines how Franciscan apologetics and polemics over the status of St. Francis and the Rule of 1223 created a climate of inquisitorial suspicion over prophecy and prophetic claims.

Keywords: Franciscans; inquisition; prophecy; heresy; miracles; Francis of Assisi; Thomas of Celano; Bonaventure; Peter Olivi; apocalypticism

The idea that claims to prophecy presented an open invitation for inquisitorial investigation and condemnation in the Middle Ages seems obvious. Augustine had established a tradition that once the revelation in Christ had been made manifest, there was no need for prophecy to reveal the unfolding of salvation history in the future. Moreover, he discouraged people from reading the Apocalypse as a prophecy. ${ }^{1}$ Robert Lerner has argued that this tradition is why very few people claimed the gift of prophecy and instead relied on the idea of an inspired reading of scripture to avoid charges of heresy. ${ }^{2}$ Lerner distinguished claims to being a prophet from being identified as a prophet by others, such as the way Joachim of Fiore was identified as a prophet. The earliest sources Lerner pointed to as evidence of this general Augustinian suspicion of prophecy, however, are from an anti-Franciscan text written in 1310 and a polemic against the Revelations of St. Bridget in 1389. ${ }^{3}$

Yet when one looks at the role prophecy played in the Franciscan Order from the time of the founder's death to the condemnation of Peter Olivi's Lectura super Apocalypsim in 1326, it becomes clear the Franciscans successfully promoted prophetic claims for their founder and their order prior to 1274 . It is also clear it was internal divisions among Franciscans over the meaning of poverty and obedience that drew the attention of the inquisition to consider the implications of prophetic claims for papal authority. ${ }^{4}$ In the end, Franciscan superiors in the early fourteenth century were successful suppressing the prophetic claims of Franciscan rigorists known as the Spirituals and their Beguin supporters in southern France. ${ }^{5}$ I am using the term "Beguins" as the inquisitors used it, namely to indicate a mixed group of men, women, and tertiaries who supported the Spirituals. ${ }^{6}$ One consequence of these

1 Augustine, De civitate dei, 18.52-53. The critical edition is Augustine, De civitate Dei (Augustine 1955, vol. 47-48), For more information see Bernard McGinn, Visions of the End: Apocalyptic Traditions in the Middle Ages (McGinn 1979, pp. 26-27). A significant source for McGinn was Robert A. Markus, Saeculum: History and Society in the Theology of St Augustine (Markus 1970).

2 (Lerner 1992).

3 Ibid., 47 n. 49

4 By the early fourteenth century, the inquisitorial procedure in Southern France consisted of several formal steps including an inquest, a summons to trial, administration of an oath, and an investigation involving the testimony of anonymous witnesses. This would be followed by a trial with the purpose of eliciting a confession by persuasion or coercion, obtaining public abjuration of the heresy, and pronouncing the sentence. For more information see Irene Bueno, Defining Heresy: Inquisition, Theology, and Papal Policy in the Time of Jacques Fournier (Bueno 2015, pp. 45-87).

5 There were also Italian Spiritual Franciscans who exhibited many of the same traits and intersect with the French Spirituals; however the differences between the two groups are complicated and nuanced. For more about the Spiritual Franciscans see David Burr, The Spiritual Franciscans (Burr 2001).

6 The term "beguin" was used in multiple ways in the early fourteenth century. It could designate any layperson who lived as if he or she was following a religious rule or who led a very pious life marked by chastity, prayer, and fasting. See David Burr, The Spiritual Franciscans (Burr 2001, pp. 91-94). 
Franciscan disputes was to create the atmosphere of suspicion over appeals to prophetic authority and to associate such claims with heresy.

The Franciscans were not alone in claiming a prophetic origin, as can be seen in the Carmelite Order's statement in 1280 that its founders were Elijah and Elisha, but their rhetoric was notably uncommon. The Carmelites did not claim to be founded by a modern prophet with an eschatological mission. Nor were Franciscans alone in seeking to predict the future through inspired readings of scripture. Rupert of Deutz (c. 1075-1129), Gerhoh of Reichersberg (c. 1093-1169), and Joachim of Fiore (c. 1135-1202), all claimed to have received a form of spiritual understanding that allowed them to interpret scripture in a way that illumined the future. ${ }^{7}$ There is one significant difference between these theologians and Francis: they were all educated, ordained, and formed in established orders.

The Franciscans identified Francis as a prophet or as having a prophetic spirit in order to explain how Francis of Assisi, who had never been formally educated, could preach and found a new order. Both were contentious claims for the friars to make, particularly after the Fourth Lateran Council declared in 1215 that all new religious orders must use an existing rule and strictly limited who could preach. Francis, who had no formal religious formation wrote his own rule, though it is more accurate to say that he negotiated what would be in the Rule of 1223 with papal advisors and Franciscan theologians. ${ }^{8}$

Given their rather novel claims for their founder and rule, one would expect that they would have provoked a great deal of suspicion and charges of heresy or false prophecy immediately; but there is almost no evidence that their prophetic rhetoric generated much of a reaction before the $1250 \mathrm{~s} .{ }^{9}$ Caesar of Heisterbach reported the Friars Minor were being accused of being false prophets as early as 1225 by the Cologne clergy, though the accusation itself was based on a prophecy made by Hildegard of Bingen rather than Augustinian theology. ${ }^{10}$ Apparently, the accusation carried little weight with the archbishop, who responded that if it was a divinely inspired prophecy, it had to come to pass regardless. ${ }^{11}$

A century later attitudes had shifted dramatically. At the instigation of Franciscan leadership inquisitors in southern France, some of whom were Franciscan, handed over as many as 82 people to secular authorities to be burned at the stake for defending the idea that Peter Olivi was a prophet from 1318 to $1326 .{ }^{12}$ It took time for concerns over Franciscan ideas related to prophecy to emerge, but the

7 Gerhoh of Reichersberg, “De quarta vigilia noctis," (Gerhoh of Reichersberg 1894). Joachim of Fiore, Liber de Concordie Novi ac Veteris Testamenti, Books 1-4 (Joachim of Fiore 1983). For a study on Rupert of Deutz, who is also known as Robert of Liege, I recommend John Van Engen, Rupert of Deutz (Van Engen 1983). The literature on Joachim is vast. Some important studies include: Herbert Grundmann, Studien über Joachim von Fiore (Grundmann 1966); Alois Dempf, Sacrum Imperium (Dempf 1929); Ernst Benz, Ecclesia Spiritualis (Benz 1934); Morton W. Bloomfield, “Joachim of Flora: A Critical Survey of his Canon, Teaching, Sources, Biography, and Influence," (Bloomfield 1957); M. D. Chenu, "Histoire et allegorie au douzième siècle," in Festgabe Joseph Lortz, vol. 2, Glaube und Geschichte (Chenu 1958, pp. 64-71); Yves Congar, "Le sens de l'economie salutary dans la théologie de St. Thomas d'Aquin," in Festgabe Joseph Lortz, vol. 2, Glaube und Geschichte (Congar 1958, pp. 86-90); Marjorie Reeves, The Influence of Prophecy in the Latter Middle Ages (Reeves 1969); Robert Lerner, "Refreshment of the Saints: The Time after the Antichrist as a station of Earthly Progress in Medieval Thought" (Lerner 1976); Henri de Lubac, La posterite spirituelle de Joachim de Flore (De Lubac 1978, vol. 1-2); Bernard McGinn, The Calabrian Abbot: Joachim of Fiore in the History of Western Thought (McGinn 1985); E. Randolph Daniel, Joachim of Fiore: Patterns of History in the Apocalypse," in The Apocalypse in the Middle Ages (Daniel 1992, pp. 72-88).

8 For a historiographical account of issues related to the composition of Rule of 1223, see Malcolm D. Lambert, Franciscan Poverty: The Doctrine of the Absolute Poverty of Christ and the Apostles in the Franciscan Order 1210-1323 (Lambert 1998, pp. 1-32); Edith Pásztòr, "St. Francis, Cardinal Hugolino, and the 'Franciscan Question'” (Pásztòr 1987). For a recent historical account see William Short, "Revising the earlier Rule: Carlo Paolazzi and the work of Kajetan Esser" in The Rule of the Friars Minor, 1209-2009 Historical Perspectives, Lived Realities (Short 2010, pp. 33-44); Dominic Monti, “'Deservedly approved by the Roman Church': The context for Papal Recognition of Francis's forma vitae" in The Rule of the Friars Minor (Monti 2010, pp. 3-32).

9 (Iglesias 1988).

10 Caesar of Heisterbach, The Life of Saint Englebert, in The Saint, vol. 1 of Francis of Assisi: Early Documents (Armstrong 1999, p. 595). The Latin text can be found in (Caesar of Heisterbach 1910, p. 650).

11 Ibid.

12 David Burr, Olivi's Peacable Kingdom (Burr 1993, p. 222). Burr cites an anonymous source in the Olivi inquisitorial process: Paris Bibliothèque Nationale manuscript lat. 4190, 40r-49v. 
seeds of the controversy were planted in the first official life of Francis, sprouted in the warmth of the Mendicant Controversy, and bore bitter fruit in the dispute over whether or not usus pauper (poor use) was included in the Franciscan vow of poverty.

As we follow the development of Franciscan ideas related to prophecy, it will become clear that initially the inquisition was not particularly concerned with individuals claiming to be prophets. What drew the attention of the inquisition was when an individual or group identified someone as a prophet in order to claim infallibility for their doctrine without explicit papal support. The initial identification of Francis as a prophet with an apocalyptic role is rooted in the earliest hagiographical sources and was promoted with papal support.

\section{Franciscan Hagiography 1226-1263}

In the spring of 1228, Pope Gregory IX commissioned Thomas of Celano to write the first life of Francis. The fact that Celano presented Francis as a preacher with a prophetic mandate for an officially commissioned life is evidence that claims to prophecy were not seen as inherently suspicious in the first half of the thirteenth century. This does not mean such claims were accepted uncritically. Innocent III had written a letter to the Diocese of Metz in which he declared that someone claiming to be sent by God should not be believed without the support of scripture or a clear miracle; however, this is a far cry from Augustine of Ancona's position in 1310 that advised one to assume that all visionary or prophetic insight is from the devil unless proven otherwise. ${ }^{13}$

Francis had a reputation as a miracle worker during his lifetime and for his miraculous stigmata upon his death. On 19 July 1228 Pope Gregory IX, after acknowledging that Satan can appear as an angel of light, declared that Francis' life had been confirmed through "numerous and outstanding miracles." 14 With the official recognition of Francis' miracles and the commission to write Francis' legend, Celano had license to portray the saint as a prophet. Gregory did not find Celano's Life of Francis theologically troubling, approved it, and declared it official on 25 February 1229.

Celano's Life of Saint Francis provides a baseline for Franciscan ideas about the prophetic nature of the saint's mission. He associated Francis' commission to preach with the commissioning of the prophet Isaiah in chapter 10: “The Lord touched his 'lips with the coal that cleanses (Isaiah 6:6),' so that he might speak of Him in words that were sweet and flowing with honey." ${ }^{15}$ Because Isaiah was cleansed by a seraph, the allusion foreshadows Francis' vision of the cruciform seraph and the miracle of the stigmata, which confirmed his preaching mission. Celano said Francis came to understand and interpret scripture without having studied in the same way as the apostles Peter and John, who amazed people with their inspired preaching though they were considered ignorant by the Jewish priests (Acts 4:13). ${ }^{16}$ In this way Francis' prophetic mission is symbolically linked with the apostolic mission to preach.

13 Innocent III, Cum ex iniuncto, in Patrologiae cursus completus ... series Latina (Innocent, III 1844-1864, vol. 214, pp. 695-98). The Patrologiae Latina will be cited as PL. Robert Lerner pointed out that Innocent's position made its way into canon law in in 1470 and that it is included in E. Friedberg, Corpus iuris canonici (Friedberg 1879-1881, vol. 2, pp. 784-87). See Robert Lerner, "Historical Introduction," in Johannes de Rupescissa, Liber Secretorum Eventuum (Lerner 1994, p. 36 n. 3). Augustine of Ancona, Tractatus contra divinatores et sompniatores in "Il Tractatus contra divinatores et sompniatores di Agostino d'Ancona: Introduzione e edizione del testo" (Augustine of Ancona 1985, pp. 62-63): "Nam in veteri lege ubi Evangelii non erat manifestata, et in ecclesia primitiva, ubi fides catholica non erat confirmata, Deus multa per sompnia et aliis modis suis fidelibus revelavit et per eos multa miracula demonstravit; sed nunc, quod veritas Evangelii est plene revelata et declarata et fides catholica plene confirmata, videmus expresse quia Deus destiterit a revelation sompniorum et visionum. Magis igitur credendum est quod talia que nunc fiunt sint dyabolice illusiones et deceptiones, quia talia Christus et apostolic eius predixerunt esse futura quam divinas revelationes."

14 The translation is from Francis of Assisi: The Saint, 565. Gregory IX, Mira circa nos in Documenta Catholica Omnia accessed from http:/ / www.documentacatholicaomnia.eu/04z/z_1228-07-19_SS_Gregorius_VIIII_Mira_Circa_Nos_ES.doc.html.

15 Thomas Celano, The Life of Saint Francis 1.10.25. All English translations are from (Armstrong 1999). The Latin text is available in Legendae S. Francisci Assisiensis saeculis XIII et XIV conscriptae, Analecta Franciscana 10, pp. 3-115. Herein cited as $A F$.

16 Thomas Celano, The Life of Saint Francis 1.10.25. 
Chapter 11 presents evidence of Francis' prophetic capacity to foretell the future. In a moment of penitential prayer, Francis is caught up in an ecstatic experience where his soul is opened wide and he clearly sees the future. He tells the brothers: "Do not be sad, because you seem so few, and do not let my simplicity discourage you. The Lord has shown me that God will make us grow into a great multitude, and will spread us to the ends of the earth."17 He also predicted three periods in the life of the brothers:

In the beginning of our way of life together we will find fruit that is very sweet and pleasant. A little later fruit that is less pleasant and sweet will be offered. Finally, fruit full of bitterness will be served, which we will not be able to eat. Although displaying some outward beauty and fragrance, it will be too sour for anyone to eat. ${ }^{17}$

Alluding to the parable of the good and bad fish, Francis predicted that with this growth the friars would become a mixed company of good and bad fish that would need to be sorted out by the Lord. Celano declared that all of these things had come to pass and concluded the chapter writing: "See how the spirit of prophecy rested on St. Francis." 19

These prophecies of bitterness and corruption were soon carried into the present or projected into the future by disgruntled friars; however, in Celano's narrative they function to set the stage for Francis to teach the brothers about the Kingdom of God in chapter 12 and to commission them to preach penance in chapter 13. While his description of Francis' ability to read hearts and to see events at a distance can be found in numerous patristic and medieval sources, his description of the brothers as having merited to receive divine revelations is less common. Celano described Francis as appearing to the brothers as a new Elijah, calling to mind the story of Elijah passing his mantle on to his disciple Elisha and suggesting that Francis's prophetic spirit had been passed on to at least some members of the community. ${ }^{20}$ Celano included stories of Francis appearing when friars were preaching in order to open up the "door of eloquence" or to open their minds to scripture. ${ }^{21}$ His suggestion that the prophetic mantle had in some sense been passed on to some of Francis' companions inspired the Spirituals as did Francis" final prophecy: "Live in the fear of God and remain in him always, for a great test will come upon you and tribulation is drawing near! Happy are those who will persevere in what they have begun: many will be separated from them by scandals that are to come."22

Celano clearly identified Francis as a prophet as part of an apologetic for the preaching mission the order had been given by Gregory IX. There does not seem to be much concern over defending poverty or responding to attacks on the validity of the Rule of 1223. Unlike later accounts, there are no overt apocalyptic themes or expectations in Celano's Life. The liturgical and hagiographical texts produced by Franciscans that followed in the 1230s and the first half of the 1240's continued to link Francis' role as a prophet, confirmed by miracles, with his preaching. It was Gregory IX that introduced the idea that Francis had an apocalyptic role in a liturgical sequence that the friars read in masses:

Last of the evil dragon's heads, holding aloft its vengeful sword, against God's people now stirred up the seventh of its savage wars (Revelation 12:3) ... . Francis, chieftain of great renown, carried the regal banner forth, assembled a council of war to move throughout the whole wide world against the rifts the dragon wrought. ${ }^{23}$

This papal portrait of Francis as arriving at the end of history invited later Franciscans to speculate further on the apocalyptic role of their founder and the order, which is evident in Bonaventure's Major

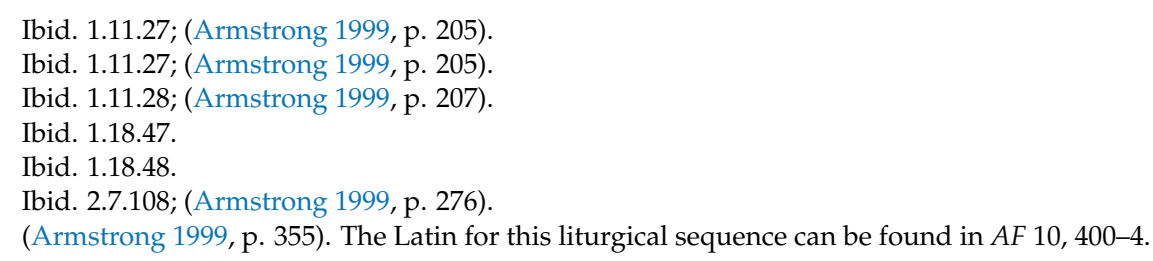


Legend. Bonaventure made the argument that Francis' doctrine and rule are infallible and absolutely certain on the basis of his status as a prophet, which had been confirmed both by miracles and by the church.

\section{The Major Legend of St. Francis}

The Major Legend was written in the heat of the Mendicant Controversy. The Mendicant Controversy began as a dispute between the Seculars, diocesan clergy on the faculty at the University of Paris, and the mendicants on the faculty. It was also related to apocalyptic expectations and questions of predicting the future through an inspired reading of scripture, which is also known as the Joachite Controversy. The Seculars used the Joachite Controversy as an opportunity to charge the friars with being false prophets. They also challenged the veracity of Francis' stigmata. ${ }^{24}$ Rather than abandon prophetic claims for the order, Bonaventure invested more significance into Francis' prophetic spirit in order to suggest that Francis' teachings were infallible. To understand how this complex of ideas came together, we need to briefly consider the Joachite Controversy.

The Franciscan chronicler Salimbene testified that many Franciscans had been interested in Joachim of Fiore's exegetical theories and had identified themselves with the spiritual men predicted by Joachim including prominent leaders like Hugh of Digne and John of Parma. ${ }^{25}$ Joachim did not look to institutional reforms for the church's betterment; instead, he grounded his reforms in the future age of the Holy Spirit and in a new exegetical method. ${ }^{26}$ He applied the term status to each of three large blocks of time corresponding to one of the persons of the Trinity. The first status, the time of the Father, is that block of time beginning with Adam and lasting until Christ—when people lived according to the flesh. The second status, the time of the Son, begins with Elisha the prophet and Josiah the king. This period is partly carnal and partly spiritual. Finally, the time of the Holy Spirit would be the time when people would live according to the Spirit. Joachim claimed that this third status had two beginnings with Elisha and St. Benedict, but that it would flourish around $1260 .{ }^{27}$

Joachim had appealed to new senses of scripture revealed to him in a series of visions. ${ }^{28}$ The central feature of his exegetical method was concordia. Concordia indicated the parallels between the people, orders and events of the Old Testament, New Testament, and the time of the church. Concordia was not, however, a spiritual interpretation of scripture; instead, it is an improved or extended literal sense of scripture. ${ }^{29}$ These parallels are so precise, according to Joachim, that one can use them to plot out the future with mathematical precision. ${ }^{30}$ Using his method, he predicted that the new age would be ushered in by a group of barefoot, preaching monks. Before this transition to a spiritual church took place, he predicted that a "Beast ascending from the earth" who would be like "Simon Magus and like a universal pope" would be defeated by an angelic pope with the aid of the last world emperor

24 Andre Vauchez, "Les stigmates de saint François et leurs detracteurs dans les dernier siècles du moyen âge" (Vauchez 1968).

25 Salimbene, The Chronicle of Salimbene de Adam (De Adam 1986, pp. 216-28). The critical edition is Cronica, ed. O. Holder-Egger (Hanover: Impensis Bibliopolii Hahniani, 1903).

26 (McGinn 1999, p. 136).

27 Joachim of Fiore, Book of Concord, 2, 4-12. The only critical edition I have seen is Liber de Concordie Novi ac Veteris Testamenti, Books 1-4, Publication of the Transactions of the American Philosophical Society, (Joachim of Fiore 1983). There is a 1517 Venetian edition for book five of this text. There is a partial English translation in Apocalyptic Spirituality (Joachim of Fiore 1979, pp. 120-34).

28 Joachim described these visions in (Joachim 1965, f. 227rb-va).

29 In the Middle Ages, scripture was seen as having either three or four senses or meanings. The literal or historical sense indicated the meaning intended by the author. The spiritual senses of scripture included allegory, anagogy, and tropology. Allegory interpreted symbols of scripture as indicating either Christ or the church, anagogy interpreted them in light of eschatological expectations, and tropology (also referred to as the moral sense) interpreted them in light of what to do or avoid. In fact, the spiritual senses are the result of reading scripture through faith (allegory), hope (anagogy), and love (tropology). For more information see Beryl Smalley, The Study of the Bible in the Middle Ages (Smalley 1964).

30 Joachim of Fiore, Book of Concord, 2.1.4: " ... exhibitione presentium certa fiat expectation futurorum." 
followed by a period of peace in the third status. ${ }^{31}$ Though various aspects of Joachim's ideas were promoted among some of the friars, very few seem to have adopted his theology as a whole.

The Franciscan Gerard of Borgo San Donnino, however, claimed that Joachim was a prophet and elevated his writings to the level of scripture. While this may seem extreme, prophecy was a topic of interest in the universities and was considered by many theologians to be infallible. ${ }^{32}$ Moreover, many important friars including the minister general, John of Parma, had publicly promoted Joachite prophecies about the Franciscans. ${ }^{33}$ In 1254 he published his Eternal Gospel, which contained a compilation of Joachim's works including the Book of Concord. Gerard's introduction, which is no longer extant, reportedly announced the beginning of the third status and claimed that $\mathrm{St}$. Francis was the Angel of the Sixth Seal in Revelation 7:2. Gerard reportedly had identified his Eternal Gospel as a third testament superseding the Old and New Testaments. ${ }^{34}$

William of St. Amour seized upon the work as a weapon to be used against the Mendicants. He excerpted 31 suspect propositions and sent them to the pope with his own work, Liber de antichristo. William identified the friars as the false prophets who precede the Antichrist. Pope Alexander IV, who retained his office of protector of the Franciscan Order, directed an inquisitorial commission established by Innocent to condemn the Eternal Gospel without discrediting the Franciscans. ${ }^{35}$ The commission wrote a report known as the Protocols of Anagni, which took issue with the possibility of a time within history when the church will be purified. The commission cited Augustine against Joachim's prediction of the purgation of the church and universal peace during the third status. ${ }^{36}$ This longstanding position was based on Christ's teaching that the wheat and the tares would remain together in the church until Christ's return at the end of history. They concluded that it was not possible to know the times and challenged the very idea that one could know when the end is near. It was clear, according to the commission, that Joachim and Gerard proposed false and new opinions out of a desire for preeminence. They were charged with incredibly exalting their own orders above all others, even above the entire church. ${ }^{37}$

According to the commission, Joachim and Gerard fit Augustine's definition of a heretic in the first book of De utilitate credenda: "The heretic, in my opinion, is one who for some temporal advantage, especially for the sake of glory and preeminence, originates or follows new opinions." ${ }^{38}$ They also cited Gratian's claim that the spirit of heresy can be seen when a group claims some type of superiority and excuses itself from discipline. ${ }^{39}$ Joachim's appeal to a new sense of scripture provided the commission

31 For more information see (McGinn 1999, pp. 141-42).

32 Nicole Bériou, "Saint François, premier prophète de son ordre dans les sermons du XIIe siècle," Melanges de l'Ecole française de Rome-Moyen Age (Bériou 1990).

33 According to the Franciscan chronicler Salimbene de Adam, John already had a reputation as a great Joachite and as a "spiritual man" at the time of his election. There is an English translation: Salimbene de Adam, Chronicle (De Adam 1986, pp. 224, 294, 301-3). John of Parma continued to defend Joachim even as he condemned Gerard. Emboldened by Alexander's actions, John actually released a joint encyclical with Humbert of Rome, his Dominican counterpart, which incorporated Joachite themes in February of 1255, just as the commission was beginning its investigation. For the encyclical see Luke Wadding, Annales Minorum, 2nd edition (Wadding 1731-1745, vol. 3, pp. 380-83).

34 Heinrich Denifle, "Das Evangelium aeternum und die Commission zu Anagni," in Archiv für Literatur und Kirchen Geschicte des Mittelalters (Denifle 1885, vol. 1, pp. 62, 68). For more information see (Anderson 2002, pp. 19-29).

35 Dominic Monti, "Introduction," in St. Bonaventure's Writings Concerning the Franciscan Order (Monti 1994, vol. 5, p. 28).

36 Heinrich Denifle, "Das Evangelium aeternum und die Commission zu Anagni," pp. 105-6: "Ecce hic dicit ecclesiam purgandam ab universis zizaniis xlii generatione, de qua non supersunt modo nisi quinque anni, et tamen tunc non ponit seculum terminari, sed pocius adhuc restare totum tercium statum habiturum quinquaginta generationes, sicut probatum est supra. Contra hoc signandum est illud Augustini xl capitulo de fide ad Petrum ubi dicit: 'firmissime tene et nullatenus dubites, aream dei esse ecclesiam catholicam et intra eam usque in finem seculi frumento mixtam paleam contineri."'

37 "Protocol der Commission zu Anagni," p. 115: "Huc usque verba Joachim et fratris Gerardi. Ex prenotatis videtur, quod iste nova et falsas opiniones confingat, et hoc maxime vane glorie causa, id est, ut exaltet huiusmodi ordinem incredibilater et intempestive super alios ordines, immo super totam ecclesiam."

38 Ibid.: "Et ideo diligenter conferenda est hec difinitio Augustini de heretico in primo libro De utilitate credendi, ubi dicit: 'hereticus est qui alicujus temporalis commodi et maxime vane glorie principatusque sui gratia falsus ac novas opiniones vel gignit vel sequitur.'" The English translation is from The Advantage of Believing (Meagher, p. 391).

39 "Protocol der Commission zu Anagni," p. 115. 
with additional ammunition for the charge of heresy from Gratian's Decretis. ${ }^{40}$ Even more damaging was their discovery of Joachim's advice to teach his doctrines in secret, in the manner of the heretics, in order to prevent the masters from reviewing them. ${ }^{41}$

Though the commissioners labeled Joachim's theology as suspect and pernicious, it was not condemned; however, Gerard was found to be a heretic and was sentenced to perpetual imprisonment. Perhaps his fate would have been better if he had not claimed that the abhominatio desolationis (abomination of desolation), which referred to a simoniacal pope, would take place by 1260 . Given that Alexander IV most likely expected to be pope in 1260, Gerard's prediction could not have been well-received. Gerard's alleged claim that Joachim's predictions concerning how the papacy, symbolically represented by Peter, was to be succeeded by a spiritual father, represented by John, also presented a direct and immediate challenge to papal authority. ${ }^{42}$ As far as we know, Gerard did not claim to be a prophet, but it was his belief that Joachim was a divinely inspired prophet that led to his downfall.

William of St. Amour, in turn, produced another apocalyptic attack on the friars reinforcing the idea that only members of the clergy can work to reform the church. The Tractatus de periculus, which circulated in an early edition in 1255 before being published in its final form in 1256, was so popular and influential it was still being printed almost 400 years after its composition and its condemnation by Pope Alexander IV. ${ }^{43}$ His polemic asked people to distinguish between the true apostles and disciples, who have been succeeded by the bishops and priests, from the false prophets or preachers, who are the mendicant orders.

The apocalyptic rhetoric of William of St. Amour and his disciples attacking the legitimacy of Franciscan ministry led Bonaventure to formulate an apocalyptic counteroffensive. In 1262 Bonaventure preached at the University of Paris that Francis was like the angel ascending from the rising sun with the seal of the living God in Revelation 7:2. This was a provocative strategy given that Gerard had actually identified Francis as the angel. Bonaventure argued the angel of the sixth seal was an appropriate symbol for Francis because he was sealed in the form of the cross by the stigmata. ${ }^{44}$ He had employed the same strategy of appealing to miracles at the height of the initial outbreak of the Mendicant Controversy in 1255, preaching: "Saint Paul exhorted Timothy to remain steadfast in what he had learned because he knew and was certain through signs and miracles that the teaching he had learned was for salvation." ${ }^{45}$ In other words, the way to distinguish between the false prophets of 2 Timothy 3:1-9 and true disciples was by the miracles associated with their teaching. "Moreover," he continued, "it pleased the Lord to endorse and confirm the teaching and Rule of St. Francis, not only by miraculous signs, but also by the marks of his own stigmata, so that no true believer could possibly call them into question on external or internal evidence." 46 Both Francis' teaching and Rule are therefore confirmed as divine revelation.

40 “Protocol der Commission zu Anagni," 115. They cite Gratian's Decretis 24.3.27: “Quicumque igitur aliter scripturam intelligit, quam sensus spiritus sancti flagitat, quo scripta, licet ab ecclesia non recesserit, tamen hereticus appelari potest." The Commission cited Isidore of Seville's Etymologies 8.3. (Isidore of Seville 1981).

41 "Protocol der Commission zu Anagni," p. 138. "Ecce qualiter in hoc prologo vult iste Joachim articulos fidei legi in abscondito more hereticorum, qui in conventiculis dogmatizant. Item inhibet, ne tractatus suus veniat ad manus magistrorum, quos etiam tam impudenter quam superbe vituperat."

42 Ibid. p. 112

43 (Faral 1950-1951, pp. 362, 372-73). (William of St. Amour 1967, vol. 6, pp. 1237-38). De periculus went through three editions before William adapted it into six sermons, the first of which was delivered on the fourth of April 1256 . There are several editions of this text, but they are difficult to obtain: William of St. Amour, De periculis novissimi temporis, appendix to Fasciculus Rerum extendarum, (William of St. Amour 1690, pp. 48-54). Part of De periculis is contained in Max Bierbaum, Bettelorden und Weltgeistlichkeit an der Universität Paris (Bierbaum 1920). Another edition is preserved in William's Opera Omnia (William of St. Amour 1632, pp. 17-72).

44 (Armstrong 2000, p. 721). All of the translations of Bonaventure's sermons on Francis are from this volume. The critical edition is (Bonaventure 1901, vol. 9). The dating of this sermon is based on its relationship to the Major Legend. See Ignatius Brady, "St. Bonaventure's Sermons on Saint Francis," (Brady 1976).

45 (Armstrong 2000, p. 513).

46 Ibid. 
Many of the themes in the sermons Bonaventure gave in this polemical context appear in the Major Legend of St. Francis. The prologue distills the prophetic themes into a concentrated apologetic. Francis preached the Gospel like the prophet John the Baptist, who practiced poverty in the desert and who preached repentance by word and deed. Lifted up in a fiery chariot, Bonaventure claimed it is reasonably accepted that "he came in the spirit and power of Elijah." ${ }^{47}$ Bonaventure concluded that this is why Francis is considered "to be like the angel ascending from the rising of the sun bearing a seal of the living God." 48 Just as this angel signed people with the cross, so too Francis signed people with the Tau of a penitential cross. Bonaventure wrote:

This conviction should be faithfully and devotedly in the forefront of our minds: not only does this advance the mission he held of calling to weep and mourn, to shave one's head and wear sackcloth, and to sign the Tau on the foreheads of those moaning and grieving with a sign of a penitential cross; even more, it confirms with the irrefutable testimony of truth that the seal of the likeness of the living God, that is, of Christ crucified, was imprinted on his body, not by natural forces or human skill, but by the wondrous power of the Spirit of the living God. ${ }^{49}$

Defending the stigmata against the attacks of the order's opponents was a critical element of Bonaventure's apologetic for Francis' prophetic status. ${ }^{50}$

At the outset of the Major Legend, Bonaventure described Francis as being filled with the spirit of the prophets, proclaiming peace, and preaching salvation in accordance with Isaiah 52:7.51 Immediately other friars manifested prophetic or visionary qualities. Bernard and Francis consulted the Gospels by opening them three times to confirm what Bernard should do, which was to sell all that he had and give it to the poor. ${ }^{52}$ This is the first of several stories of friars exercising a prophetic reading of scriptures. Giles, although simple and unlearned, was raised to exalted contemplation. Sylvester joined Francis as the result of a vision he had of Francis defeating a dragon that was encircling the town of Assisi. 53

Bonaventure described Francis as being so overcome with the news of Sylvester's vision that he clearly saw the future of the order. Bonaventure gave this rendition of Francis' prophecy concerning the order: "Be strong, my beloved ones, and rejoice in the Lord. Do not be sad because you are so few, nor afraid because of my simplicity or yours. For the Lord has shown me in truth that he will make us grow into a great multitude and will spread us in countless ways by the grace of his blessing." 54 Bonaventure omitted the material concerning the decline of purity as the order would grow, most likely to avoid giving further ammunition to the order's detractors. When he brought up Francis predicting trial and tribulation, he presented it as an exhortation to persevere rather than a prophecy of something more specific. ${ }^{55}$

The stories of Francis appearing to the brothers in a brilliant fiery chariot and of his ability to examine the consciences of others provided Bonaventure an opportunity to present Francis' teaching and way of life as infallibly certain. When Francis disclosed many things that transcended human reason about the future of the order, Bonaventure concluded that "the Spirit of the Lord had come to

47 Bonaventure, The Major Legend of Saint Francis, prologue. The English translation is from (Armstrong 2000, p. 526). The Latin text can be found in (Bonaventure 1941, pp. 557-652).

48 Ibid.

49 Ibid.; (Armstrong 2000, pp. 527-28).

(Rambow 2017, pp. 337-41).

1 Bonaventure, Major Legend 3.2.

2 Ibid. 3.3. For some more information on Bonaventure and the various sources for his understanding of a prophetic reading of scripture see Daniel P. Horan, OFM, "Bonaventure's Theology of Prophecy in the Legenda Major: Sources and Interpretation," (Horan 2014). Horan's article is focused on intellectual history and structural analysis.

53 Bonaventure, Major Legend 3.5.

54 Ibid.; (Armstrong 2000, p. 545).

55 Ibid. 14.5 
rest upon him in such fullness that it was absolutely safe for them to follow his life and teaching." 56 At this time, Bonaventure noted, Francis called their way of life the Order of the Brothers of Penance because it admitted laity and clerics as well as the married and unmarried. Just as Bonaventure had suggested that prophetic action had passed from Francis to some of his followers, now he pointed to the miracles performed by the members as proof of the merit of the order. ${ }^{57}$

After recounting several miracles, visions, and apparitions, Bonaventure turned to the composition of the rule. In his account, Francis had a revelation from God that he should gather together crumbs and form a host out of them. Then he should feed the host to all who wanted to eat. When they ate without devotion or showed contempt for the host they received, they appeared to have leprosy to him. Bonaventure wrote that God revealed the meaning of the vision directly to Francis: "Francis, the crumbs of last night are the words of the Gospel; the host is the rule and the leprosy is wickedness." 58 Thereupon he is led by the Holy Spirit up Fonte Colombo with two brothers to condense the rule into a shorter version as dictated by the vision. "There he fasted, content with only bread and water," Bonaventure continued, "and dictated the rule as the Holy Spirit suggested it to him while he was praying. ${ }^{159}$ When the document was lost after a few days, Francis miraculously reproduced it in the same manner as if the words came directly from God.

The rule is the result of a direct revelation from God in the Major Legend. Lest anyone miss the absolute authority of the rule, Bonaventure wrote:

Fervently exhorting the brothers to observe this rule, Francis used to say that nothing of what he placed there came from his own efforts but that he dictated everything just as it had been revealed by God. To confirm this with greater certainty by God's own testimony, when only a few days had passed, the stigmata of our Lord Jesus were imprinted upon him by the finger of the living God, as the seal of the supreme Pontiff, Christ, for the complete confirmation of the rule and the commendation of its author ... ${ }^{60}$

Bonaventure presented Francis as having two mutually reinforcing claims to authority. Francis carried the seal of Christ in the stigmata, which was a sign from heaven to preach, and he had been given the authority to preach by the pope, who also approved his Rule of 1223.

Whereas scripture calls for two or three witnesses, Bonaventure reminded his audience that Francis had a multitude of witnesses providing superabundant testimony to the stigmata so that he was overwhelmingly credible. He pointed to the quality and great number of witnesses to the stigmata including Brother Illuminato, Cardinal Hugolino (Pope Gregory IX), Cardinal Thomas of Capua, Cardinal Rainerio Capoci of Viterbo, and Pope Alexander IV. ${ }^{61}$ He concluded that Francis' life and example showed with such clarity Gospel perfection that "no truly devout person can reject this proof of Christian wisdom", "no truly believing person can attack it", and "no truly humble person can belittle it". ${ }^{62}$

Rather than retreat from the claim that Francis was a prophet, Bonaventure advanced the claim on the basis of miracles, particularly the stigmata. Moreover, he made it clear that some of the other original companions also manifested prophetic powers and performed miracles. Finally, he claimed that the spirit of prophecy is widely diffused into the souls of the holy, even outside of the order. ${ }^{63}$ Bonaventure developed all of these themes in his final series of sermons in 1273 , the Collations on the

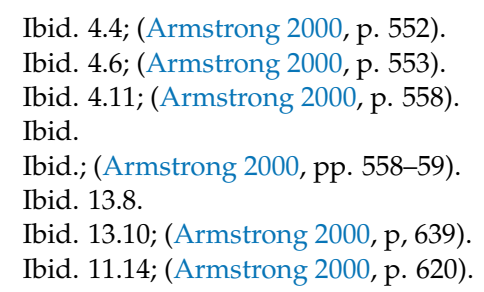


Six Days, in a way that encouraged resistance to attacks on poverty and that explicitly taught that prophecy is infallible.

\section{Prophecy in the Collations on the Six Days}

Bonaventure largely moved away from identifying Francis as a prophet in the four sermons he preached on Francis in Paris in 1266 and 1267. Instead, he began to advance an argument that Francis was like another St. Paul as a justification for Franciscan preaching. He also claimed St. Paul as a precedent for Francis' stigmata based on Galatians 6:17. But in the Collations on the Six Days, a series of doctrinal sermons delivered in the spring of 1273, Bonaventure returned to presenting Francis as a prophet and the Friars Minor as an order distinguished by prophetic action (habitus). Though there is no clear evidence of why he returned to his prophetic apologetic, the reemergence of the Mendicant Controversy and growing opposition from the bishops most likely played some role.

There were multiple problems emerging with the bishops in the 1260s and 1270s. Bishop Florentius of Arles, who had served on the inquisitorial commission that condemned Gerard of Borgo San Donnino for the Eternal Gospel, was not satisfied with the fact that Joachim of Fiore's theology had not been condemned. He condemned the Introduction and the prohibited distributing or using the teachings of Joachim at the provincial Council of Arles in $1263 .{ }^{64}$ Florentius also managed to have Joachim's doctrine of three ages labeled as "pernicious" by the provincial council. These actions were necessary, according to Florentius, because of the ongoing activities of Joachite regulars who were hiding and preserving the writings of Joachim in their houses. Some of these regulars, probably the majority, were Franciscans.

In 1267, a provincial synod in Rheims restricted the number of Friars Minor who could preach or hear confessions. This event seems to have revived the Mendicant Controversy. From 1268-1271 two of William of St. Amour's disciples, Gerard of Abbeville and Nicolas of Lisiex, began to resurrect his polemic against the friars. ${ }^{65}$ Because Clement IV had been a strong supporter of the Franciscans, the Seculars were emboldened by his death in November of 1268. The papacy remained vacant until the election of Gregory X in September of 1271, which created an environment conducive for anti-mendicant opposition to grow. With the election of Pope Gregory X in 1272, the Franciscans found renewed papal support. Nonetheless, episcopal opposition to the friars was so entrenched by the time Bonaventure and Gregory arrived in Lyons to prepare for the council in 1274, they were forced to call a special chapter meeting prior to the opening of the council in order to pass legislation which would mollify the bishops. ${ }^{66}$

While this context would seem to make it dangerous to claim that the Friars Minor had a prophetic mission, all of the sources that had justified Francis' preaching mission and founding of the order rested on the claim that Francis was a prophet as verified by his miracles and form of life. So it is not surprising that Bonaventure returned to the issue of prophecy and its relationship to the Franciscan Order in the Collations on the Six Days. The first significant discussion of prophecy in the Collations connects it to the fullness of understanding considered as the key to contemplation. He preached:

The two cherubim are the two testaments whose gaze is directed upon Christ. Then he opened their minds, when they understood the scriptures, meaning that the book of scriptures is understood precisely through that key, the Incarnate Word, the one eminently concerned with the works of restoration. ${ }^{67}$

64 The text is cited in "Das Evangelium aeternum und die Commission zu Anagni," 90.

65 Yves Congar, "Aspects Ecclésiologiques de la Querelle entre Mendiants et Séculiers dans la Seconde Moitié du XIIIe Siècle et le Début du XIVe," Archives d'Histoire doctrinale et litteraire du moyen age (Congar 1961, vol. 27-28, pp. 44-52).

66 "Statutes Issued by the Chapter of Lyons," in St. Bonaventure's Writings Concerning the Franciscan Order, 255-56. See also (Emery 1954).

67 Bonaventure, Collations on the Six Days, 3.11. The critical edition of the Collations on the Six Days is contained in (Bonaventure 1934-3964., vol. 5). The translation is from (De Vinck 1970, p. 47). 
Thus it is Christ who is the mercy seat and all the symbols of scripture find their meaning in Jesus Christ. Since Christ bestows all of the gifts as their principle, including those found in the church triumphant, Christ is also called the father of the age to come. ${ }^{68}$

The Inspired Word, the third key to understanding, opens up the meaning of all visions and revelations. Indeed, there is no possibility of revelation except through the Inspired Word. ${ }^{69}$ Bonaventure drew upon the figures of Joseph and Daniel to explain the different types of vision including the physical, imaginary, and intellectual visions. Because Daniel 1:17 says that God gave to Daniel the understanding of all visions and dreams, Bonaventure used him as his primary example. A physical vision is one where people can see it, such as the hand that wrote on Belshazzar's wall, and an imaginative vision can be seen in Nebuchadnezzar's dream of the golden statue. ${ }^{70}$ Neither physical nor imaginative visions are useful, however, without intellectual vision necessary to interpret them. It is the gift of the intellectual vision that allowed Daniel to be able to understand all visions and dreams. ${ }^{71}$ Bonaventure distinguished such interpretations, which can point to the future, from prophecy.

Prophecy is, according to Bonaventure, one of six additional types of vision granted through the Inspired Word in this life. The six, from most to least common, are the visions of natural understanding, of faith, of the intellect taught by scripture, of contemplation, of prophecy, and of ecstasy. ${ }^{72}$ The first two types of vision are held by many, the second two are given to few, and the third two are given to very few. Later in the Collationes he connected the study of scripture and contemplation with what he identified as the prophetic action (habitus) of the Franciscan Order. ${ }^{73}$ Such interpretations, however, are qualitatively different than the vision of prophecy. He wrote:

The fifth vision, which comes about through an understanding enlightened by prophecy, is still higher than the preceding ones, in that contingent things are seen infallibly, which comes about through a certain kind of sight looking into the eternal mirror. The contingent is changing and varied: if then a prophet sees with infallibility and certainty, everything he sees must be considered within infallible truth. ${ }^{74} 0$

Of course, this had tremendous implications for the Franciscan Order because the friars maintained that Francis was a prophet, which implied that the Rule of 1223 was infallible. Bonaventure also indicated that there might be other prophets as well. Lest he be interpreted as a radical, he closed this collation explaining how the Inspired Word comes in a radiation that moves through the angelic and ecclesiastical hierarchies. ${ }^{75}$ Prophecy was an ecclesial reality for Bonaventure.

Whereas prophecy is infallible, Bonaventure introduced the idea that a contemplative or speculative reading of scripture can also lead one to understand the future. Indeed the Collations seek to interpret a series of visions found in the six days of creation. Bonaventure must have had the Protocols of Anagni's charge of heresy against Gerard for interpreting scripture according to senses that are not demanded by the Holy Spirit in mind, which is why he spent a considerable amount of time addressing how new interpretations of scripture are both possible and even necessary. ${ }^{76}$ Responding to the ambiguity over the term intelligentia and its cognates, Bonaventure distinguished between two primary meanings of intelligentia in relation to scripture. First, he used the waters on the third day to show there are four principal intelligentiae of scripture, which are finite in number, absolute in authority,

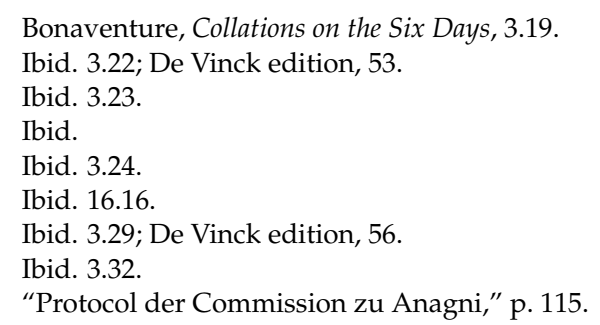


and necessary for interpreting scripture. ${ }^{77}$ But he also argued that intelligentiae can also be understood in terms of the seeds and fruits of scripture or the various theories drawn from a pious reading of scripture using the four senses. ${ }^{78}$ While the senses are finite, the theories or seeds are virtually infinite; indeed, he states that all of the interpretations that had been made are as a single drop from the sea in relation to those to come. ${ }^{79}$

Employing the image of the Holy Spirit as author, Bonaventure argued that scripture must contain many possible interpretations. If a human author can write a work using the present tense to indicate the past, present and future, then the Holy Spirit must be able to write a book that actually contains the past, present and future. ${ }^{80}$ Whereas great human authors can write books that are still meaningful through the ages, the Holy Spirit's book becomes, in the various possible interpretations, a mirror, in which people see individual reflections in a slightly different way depending on their own place in history and in the journey of their own spiritual life. ${ }^{81}$ In other words, an inspired reading of scripture leads to an understanding of subjective truth.

History, as the study of change or development, provided Bonaventure with the justification for new interpretations of scripture and developments in the church. Still, not all interpretations or developments are legitimate. Knowledge of the times allows one to discern from what tree a seed has fallen and what type of fruit it will bear. "One who ignores the past," Bonaventure warned, "cannot know the future." ${ }^{\prime 2}$ Prophetic exegesis is a discipline that grows from the seeds of the sacraments of scripture, but he maintained it must be confirmed in the tradition. Shifting analogies, Bonaventure told the brothers that scripture is like a mirror reflecting the different things held up to it. This is the true meaning of Daniel 12:4, which says that many shall pass over and knowledge will be increased. Daniel's prophecy indicates the fact that one person and another see different things when they look in the same mirror. ${ }^{83}$

Before discussing the different theories, Bonaventure singled out a few theories as containing the rationes seminales or seminal reasons for understanding scripture. These seminal reasons or interpretations are grounded in either scripture or traditions affirmed by the church. For example, the primary theory is based on the six days of creation and the following Sabbath. This theory shows how the mystical body of Christ has six ages, a seventh running concurrent with the sixth, and an eighth day. ${ }^{84}$ He also offered several other seminal theories that are not provisional that need not detain us. ${ }^{85}$ Someone who ignores the seminal theories, he warned, cannot reach the meaning of the mysteries of scripture. All of these seminal matters, Bonaventure told the brothers, must be considered in an absolute way, and all of the theories that come forth must be compared to their source in the seminal reasons. ${ }^{86}$

Though his discussion of the seminal theories was general in terms of future expectations, Bonaventure presented his own interpretation of the times based on his reading of scripture. He divided history into three major periods composed of seven times each, which is structurally similar to Joachim's understanding of history. ${ }^{87}$ Bonaventure placed himself and his brothers in the sixth time of the third period of history. The sixth time of the church is the time of clear doctrine when three

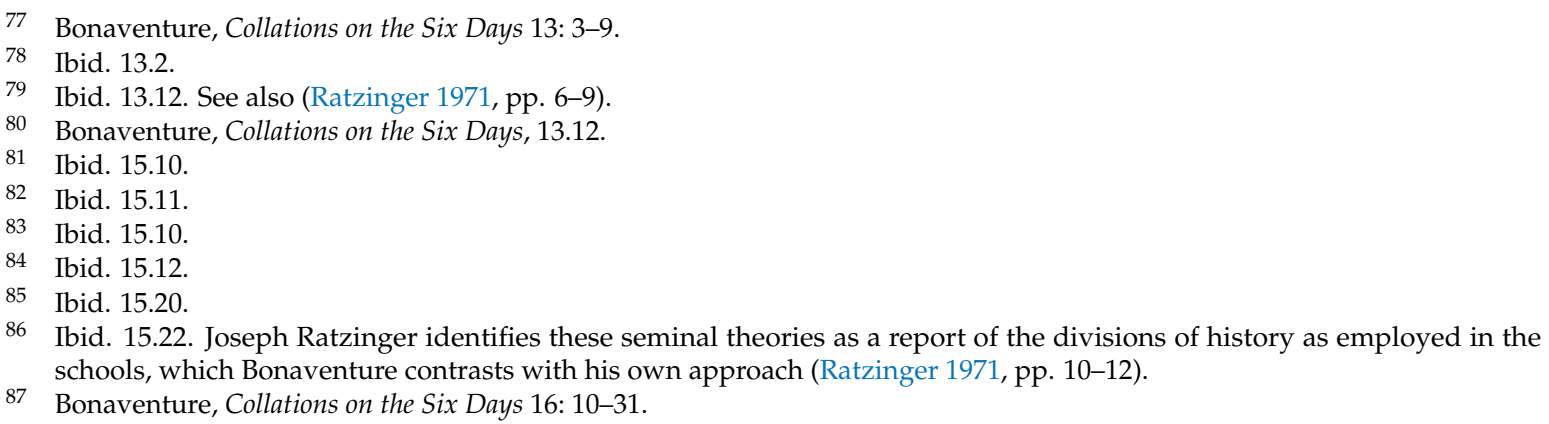


things occur: the height of victory, of teaching, and of prophecy. ${ }^{88}$ He saw the height of victory and of teaching in Charlemagne who had a series of triumphal victories and established schools. Charlemagne corresponds to the angel of the Lord who slew one hundred and eighty-five thousand enemies of Jerusalem referred to in II Kings 19:35. Bonaventure enigmatically states that because Charlemagne was like an angel sent by the Lord and the sun, the tide of tribulations receded and peace came to the church temporarily. ${ }^{89}$

After Charlemagne's death, his successors renewed the tribulations of the church. Bonaventure identified Henry IV and Frederick the Great as two examples of tribulations or opposition to the reform efforts of the church. Both men attempted to establish their own popes, but Bonaventure focused upon Frederick the Great who wished to destroy the church. ${ }^{90}$ This destruction was prevented by the angel ascending from the sun (Apocalypse 7:2). ${ }^{91}$ But rather than embarking on apocalyptic speculation, Bonaventure used the symbols to make an appeal for unity. Francis, as a type for the members of the church after the fall of the Antichrist, reveals the necessity for Franciscan unity. Bonaventure preached,

For it was necessary that in this time there come one (unus) order, having, of course, a prophetic character (habitus) similar to the order of Jesus Christ, and the head of this order would be an angel ascending from the rising sun, having the seal of the living God, and conforming to Christ. ${ }^{92}$

It was necessary for this order to be one order because it prophetically points to the fulfillment of the promises concerning the church in the seventh time, when there will be peace. ${ }^{93}$ Bonaventure warned that an attempt to divide the Franciscan Order is an attempt to strip it of its prophetic character. Still, he did claim that now, for the first time, the understanding of scripture would be given to a single person or a great number of people. The recorder for the Collations included a comment that Bonaventure believed this understanding would be given to a great number of people. ${ }^{94}$

Did Bonaventure believe that Francis was literally the Angel of Revelation 7:2 and that the final events of the Apocalypse were about to unfold? There are several reasons to answer in the negative. First, this interpretation is presented as a provisional theory. More significantly, Bonaventure stressed that the events prophesied in the Apocalypse are still in the future. Using two figures who indicate the contemplative church, he preached, "Rachel as yet is to conceive and give birth, and Benjamin is yet to be born." ${ }^{\prime 95} \mathrm{He}$ insisted the opening of the book of scripture in Apocalypse 5:5 and the breaking of the seven seals have not come yet. ${ }^{96}$ "For there is not as yet any city of God," Bonaventure proclaimed to the brothers, "nor any sealed, unless you are sealed by the Holy Spirit for the purpose of pious veneration." ${ }^{\prime 97}$

Regardless of whether Bonaventure literally saw Francis as the angel of the sixth seal, he certainly believed that Francis played a providential role in history. Bonaventure associated Francis with the Seraphic Order because of his ecstatic experiences, which took place prior to his becoming a Franciscan. By way of contrast, the Franciscans are members of the Cherubic Order, which he identified as prophetic in character because it proceeds by knowledge and a speculative reading of scripture. ${ }^{98}$

88 Ibid. 16.29 .

89 Ibid.

90 Ibid. Both emperors struggled with the popes over the issue of who had the right to install bishops and abbots into offices.

91 Ibid. Bonaventure also used this symbol in his apologetic, On Evangelical Perfection, 2.12. The critical edition for his treatise on perfection is (Bonaventure 1889, vol. 5).

92 Bonaventure, Collations on the Six Days, 16.16 .

93 Ibid. 16.30 .

Ibid. 16.29 .

Ibid. 20.27.

Ibid. 20.15 .

7 Ibid. 20.27.

98 Ibid. 22.6. Bonaventure used Gregory the Great's ordering of the angels in this way of looking at the hierarchy rather than the standard Dionysian ordering. The highest order for Gregory the Great were the thrones, followed by the cherubim and 
Francis' ecstatic experiences point to the emergence of an order that proceeds by elevations and ecstasy, but Bonaventure refused to elaborate on what this Seraphic Order was or would be. ${ }^{99}$

The ambiguities and unfinished quality of the Collations on the Six Days left a great deal of open ground around prophecy and a prophetic reading of scripture, but Bonaventure laid the foundations for the theology Peter Olivi. Bonaventure had made the Rule of 1223 and the Franciscan way of life absolute. Not only was the Franciscan order divinely established, it was destined to face opposition by the forces of the Antichrist and to overcome that opposition. Yet Bonaventure did not have to identify Francis as a prophet on his own authority. Bonaventure drew upon Gregory IX's authority as the one who approved Celano's legend and who invested Francis with apocalyptic significance. He promoted new interpretations of scripture and relativized prior interpretations; but since his aim was to reinforce papal authority, he did not draw the attention of the inquisition. When the popes began to involve themselves in questions over the meaning of the Rule of 1223, these elements of his theology became the grounds for resistance. Peter Olivi held many positions that are evident in Bonaventure's writings, which he and other friars promoted to the Beguins in Southern France.

\section{Peter Olivi and the Franciscan Spirituals}

Peter Olivi was the intellectual leader of the French Spirituals who were advocating for a more rigorous interpretation of how to observe poverty and who felt that the order had lost its purity. Like Bonaventure Olivi maintained the infallibility of prophecy and saw it as the fruit of contemplation, but he rejected Bonaventure's position that the prophets see into the eternal mirror. His source was Pseudo-Dionysius (Denys) who said that the highest vision is found in contemplation, not of God, but of the things below God. ${ }^{100}$ Olivi cited Denys' claim that the types of visions experienced by the prophets and holy fathers were formed in their minds by angels to argue that such visions take place in a created mirror. ${ }^{101}$ Though not grounded in eternity, prophetic certitude is possible as the result of a "conviction of inevitability" granted to the prophet. ${ }^{102}$ One sign of such inevitability is a sensation of sweetness. ${ }^{103}$ Even so, he admitted that there were degrees of certitude associated with prophetic visions because prophets do not always understand or fully understand what the vision means. ${ }^{104}$ He recognized that the scriptures indicate different types of prophets from those who are bad, like Balaam, to the illustrious, like Daniel.

Olivi claimed that prophecy is a type of habitus that involves three dispositions that correspond to prophetic certitude. The first clarifies the intellect, the second leads to a habitual understanding of truth, and the third leads to certain conviction. He identified Joachim of Fiore as an example of this prophetic habitus as well as to consider the question of whether a prophetic insight can be wrong. Olivi wrote:

then the seraphim. Later in these collations, he used the Dionysian ordering to describe the hierarchization of the soul. For more information, see (Anderson 2002, pp. 155-88).

99 Bonaventure, Collations on the Six Days, 22.22.

100 Olivi, Super Isaiam, Super titulum, in Peter of John Olivi on the Bible: Principia Quinque in Sacram Scripturam, Postilla in Isaiam et in I ad Corinthios (Olivi 1997, p. 195): Unde ille ipse in libro De mystica theologia dicit quod summae rationes visorum quae contemplantibus in vertice montis, id est, contemplationis, apparent, non sunt ipse Deus, immo sunt inferiores ipso. Pseudo-Dionysius, Mystical Theology 1.3, contemplantibus in vertice montis, id est, contemplationis, apparent, non sunt ipse Deus, immo sunt inferiors ipso. Pseudo-Dionysius, Mystical Theology 1.3.

101 (Olivi 1997, pp. 195-96); Pseudo-Dionysius, Celestial Hierarchy 4.2.

102 I borrowed the phrase "conviction of inevitability" from David Flood and Gedeon Gál's introduction to the Isaiah commentary in Peter John Olivi on the Bible, 157.

103 (Olivi 1997, p. 196): "Scioque me vidisse personam sanctissimam, secreto mihi referentem, quod in locutionibus propheticis, quae intra cor eius a Deo modo intellectuali fiebant, in principio gustum dulcoris in eis sentiebat et cum gustu annexo formabantur in corde eius, procedente vero tempore fiebant in ea sine huiusmodi gustu." David Burr sees this as evidence that Olivi is not comfortable with understanding prophecy and contemplation in strictly intellectual terms The Spiritual Franciscans (Burr 2001, p. 84).

104 (Olivi 1997, p. 196). 
And in this way Joachim, in his Liber de concordia and Expositio Apocalypsis, says he received the entire concordance of the Old and New Testaments in the form of general rules from which he later deduced certain things, some of which (it seemed to him) he considered himself to know as certain conclusions, while he saw others as probable conjectures which might be erroneous. It is just the same with the natural light of intellect joined to us from the beginning of our condition. Through it, without any argumentation, we know first principles, and from these we infer some conclusions necessarily, others only probably. In the latter case we are capable of error, yet it does not thereby follow that the light itself is not from God, or that it is in itself false. I say this because there are those who wish to conclude that Joachim's whole understanding was from the devil or by conjecture of the human imagination, because in certain particulars what he said was merely opinion and occasionally perhaps even false. ${ }^{105}$

One significant problem with his defense of Joachim is that he does not provide any clear way to distinguish between what is certain and what is conjecture. He created more ambiguity by claiming that just as angels sometime bring the key to understanding a vision to a prophet immediately, God sometimes uses angels to lead people to new truths from scripture in an instant. ${ }^{106}$ The distinction between what is certain and what is not seems to be based on the certitude of the purported prophet or exegete. This would seem to invite the charge of appealing to senses of scripture that are not received by the church, but no such charge was brought against him during his lifetime. ${ }^{107}$

The controversy that Olivi faced was due to his advocacy for the position that usus pauper or poor use was intrinsic to the Franciscan vow. This started a controversy among Franciscan lectors in southern France that soon drew in the entire order. As the debate unfolded, the supporters of usus pauper raised questions about the authority of their Franciscan superiors. There does not seem to be much difference in practical implications between those who believed their vow obliged to poor or restricted use and those who believed it was a necessary part of following the rule, but the partisans invested a great deal of significance into the debate. ${ }^{108}$ As part of his argument, Olivi connected the attack by some Franciscans on usus pauper to the broader attack on evangelical poverty that he saw in the works of Seculars and of Dominican critics of the friars. ${ }^{109}$

All of these themes came together powerfully in Olivi's incredibly complex commentary on the Apocalypse. Though he clearly felt free to deviate from Joachim, the work is deeply indebted to Joachim and the idea of concordances between the scriptures providing insight to the future. Bonaventure's exploration of the symbols of the Antichrist was so general as to be a type of prophetic tropology, but Olivi presented an interpretation that indicated a series of events in an indeterminate but imminent future.

Olivi interpreted the struggle over usus pauper as a sign that the fifth seal of the Apocalypse had been opened, which he saw as indicating the emergence of a mystical Antichrist within the church. He predicted the mystical Antichrist would attack Franciscan poverty and would reign until the destruction of the corrupt church. ${ }^{110}$ At other times he placed the mystical Antichrist in the sixth

105 Translation is from (Burr 2001, p. 83; Olivi 1997, pp. 197-98).

106 (Olivi 1997, p. 198): “. . . sic per angelos aliquid notabile, quod est quasi ostium intelligentiae visionis aliquando ei qui videt vel audit visionem proponitur ex quo statim incipit advertere intelligentiam visionis illius. Et iste est unus modus per quem Deus subito docet maxima de Scripturis sacris, quia quaedam sunt ibi velut grana auri hinc inde dispersa, quae sunt quasi stillae et quaedam ostia et principia aperientia occultos et diffusos sensus Scriptutaram. Datur enim homini tunc advertere corollariam habitudinem illorum ad multa, quae latent communiter intuentes Scripturas."

107 David Burr found a manuscript written by the first theologian tasked with examining Olivi's apocalypse commentary, who saw the commentary as the reemergence of Gerard of San Borgo Donnino's heresy. See (Burr 2014, p. 419).

108 (Olivi 1997, p. 136). See also (Madigan 2003, pp. 57-66).

109 (Olivi 1997, p. 88; Madigan 2003, p. 6).

110 Peter Olivi, Lectura super Apocalypsim 67ra-rb; 91ra-93rb. Kevin Madigan provides a useful summary of his expectations around the mystical Antichrist: (Madigan 2003, pp. 49-54). For more detailed information see (Olivi 1997, pp. 132-97). 
period of the church, but since the fifth and sixth periods overlap he could afford the ambiguity.111 Though he was somewhat vague as to when he expected this to happen, it was clear that he thought it would be soon because he had placed himself at the end of the fifth period after the sixth period had already begun to unfold. ${ }^{112}$

Olivi's apocalyptic polemic against his opponents over usus pauper had important consequences for the French Spirituals and the Beguins. By identifying opposition to usus pauper with the activities of the Antichrist and its supporters with the remnant of the faithful, he encouraged his followers to absolute opposition to any attempt to claim that usus pauper was not inherent in the Rule of 1223. The more pressure that was brought to bear on the Spirituals and their lay supporters over usus pauper, the more Olivi's followers saw their actions as confirmation of Olivi's doctrine. To stamp out dissent, Franciscan leaders reached out for support from the papacy to resolve the dispute. Papal involvement seemed to further confirm Olivi's apocalyptic expectations. Even so, it took almost ten years after his death for concerns over his understanding of prophecy and of prophetic exegesis to come to the attention of the inquisition. It was only when his followers identified him as a prophet and claimed infallibility for his doctrine that the inquisition became involved.

\section{From Poverty to Prophecy}

The posthumous condemnation of Olivi's teachings in 1299 at the Franciscan General Chapter did not identify his understanding of prophecy or his interpretations of the Apocalypse as a particular concern. The brothers were told they must abjure three of Olivi's positions: that usus pauper is part of the vow, that Christ was wounded with a spear before he died, and that they should not venerate someone who was not officially canonized. ${ }^{113}$ The last abjuration points to the fact that Olivi quickly came to be revered as a saint. Though the Friars Minor made an effort to suppress what they identified as Olivi's superstitious sect, initially they were not specific as to what identified its members. ${ }^{114}$ In response to a question from the Provence provincial chapter as to what constituted their superstitions, the minister general, John Minio de Murrovalle, identified their defense of usus pauper as the problem. ${ }^{115}$ As the controversy and its attendant persecutions unfolded, it gradually became clear that Olivi's underlying theology of history and of prophecy was the source of resistance.

With the decision of the General Chapter in hand, the minister general was successful in enlisting Boniface VIII's support for suppressing those who adopted Olivi's position on poverty or who venerated him as a saint. ${ }^{116}$ In 1299 a rigorous effort was made to suppress the French Spirituals committed to usus pauper using Franciscan visitors who were reported to have found enough errors to compose a great book of them. ${ }^{117}$ Unfortunately, the existing evidence shows little concern with prophecy, revelations, or other related matters. David Burr notes that Boniface was concerned enough with Olivi's apocalypse commentary to ask Giles of Rome to write a refutation, but the refutation was never written and we can only speculate as to what prompted Boniface. ${ }^{118}$

There is evidence of concerns over apocalyptic expectations that come from a provincial council in Beziers. The acts of the council contain a complaint about a group of men from an approved order stirring up the Beguines by teaching that the time of the Antichrist was either near or had

\footnotetext{
There is a new critical edition and English translation that has recently been published: Peter of John Olivi, Commentary on the Apocalypse, (Olivi 2017).

111 (Burr 2001, p. 91).

112 Ibid. p. 76.

113 (Burr 2001, pp. 88-89).

114 (Amorós 1931, pp. 504-5). The charge that Olivi was the head of a superstitious sect was raised before his death by his provincial minister, Arnold of Roqueville, along with 35 members of his province sometime in the late 1280s, but I think this most likely refers to fellow travelers among the friars. See (Burr 2001, p. 92).

115 (Lambert 1998, p. 181).

116 (Burr 2001, pp. 88-89).

117 Ibid. p. 88; (Amorós 1934, p. 403).

118 (Burr 2001, p. 88).
} 
already begun in 1299 , but the complaint is too vague to be helpful. ${ }^{119}$ Though it was likely that the men from the religious order were Franciscans, apocalyptic speculation was not confined to the Spiritual Franciscans. The provincial council did not mention usus pauper, prophecy, revelations, visions, or spiritualis intellectus. In the end, the complaint in Beziers does not seem to have culminated in action or to have influenced subsequent events.

More than a decade after Olivi's death, two Franciscans, Raymond of Fronsac and Bongratia of Bergamo, composed a list of errors that provide the first clear evidence of concerns over Olivi's prophetic exegesis of the apocalypse. They sent the list to Pope Clement V for his consideration. For the first time Olivi was charged with "false and fantastic prophecies" that disparaged the church. They also charged that his followers saw his interpretations as inspired by the Holy Spirit and attributed to them infallible authority as articles of faith. ${ }^{120}$ Though Olivi never claimed to be a prophet, his followers promoted him as one. Pope Clement V, however, chose not to pursue the matter of prophecy and it was not considered at the Council of Vienne (1312).

The situation changed shortly after the election of Pope John XXII, but initially his concern was obedience. In 1317 John promulgated the bull Quorumdam exigit, which defined that it was up to the Franciscan superiors to decide what constituted appropriate use of goods. If the friars refused to accept their superior's decisions, they were referred to the inquisition for rejecting Quorumdam exigit. This clarified the central issue as a matter of obedience to ecclesial authority rather than how the order understood poverty. Within a week the Franciscan minister general, Michael of Cesena, summoned the French Spirituals being held in Avignon and asked them whether they would obey the bull and whether the pope had the power to implement the precepts it contained. Roughly half of the 50 or so friars answered affirmatively and submitted to the bull. The remaining 25 were handed over to the Franciscan inquisitor, Michael le Moine. ${ }^{121}$ Le Moine convinced all but five to submit to the bull.

In the end, four Franciscan friars were burned at the stake in Marseilles on 7 May 1318 and one was sentenced to perpetual imprisonment for the heresy of denying papal authority. After listing their heretical errors, he identified the poisonous source of their heresy as Olivi who had attacked the authority of the Roman Church. Though the inquisitor reserved final judgment of Olivi's works since they were being investigated at the direction of the pope, he warned people not to read Olivi's books or revere him as a saint. ${ }^{122}$

The investigation of Olivi's writings that Le Moine referred to was instigated by Pope John XXII in 1318 and continued until 1319. An inquisitorial commission of eight theologians, two of whom were Franciscans, examined Olivi's commentary on the Apocalypse and identified 60 articles for censure. Twenty-three were related to his prophetic interpretations of scripture. Fifteen of the articles rejected the idea that the knowledge and virtue of the sixth and seventh periods is superior to that of the Apostles. Eight censured the claim that the new spiritual church will surpass the current church as the church surpassed the synagogue. ${ }^{123}$

In January of 1318, John XXII released the bull Gloriosam ecclesiam, which listed the errors of an amalgamation of Spiritual Franciscans, Fraticelli, Beguins and other fellow travelers. ${ }^{124}$ Three of the errors listed are related to Franciscan ideas about prophecy. First the pope claimed that these heretics write about a carnal and a spiritual church, where the carnal church is led by the pope and diocesan clergy and the spiritual church is composed of themselves and their followers. He objected to claims that the identifying mark of the spiritual church is poverty. The second was that the meaning

119 Ibid. pp. 91-92. Malcolm Lambert does see this as evidence of the activities of the lay supporters of the Spirituals: (Lambert 1998, p. 184).

120 (Burr 2001, p. 151).

121 Malcolm Lambert presents a very detailed account of these events in (Lambert 1998, pp. 221-29).

122 (Burr 2001, pp. 203-4).

123 Ibid. pp. 208-9.

124 Malcolm Lambert argued this was particularly aimed at the Celestines in (Lambert 1998, p. 229). The bull can be found in (Eubel 1898, pp. 137-42). 
of the scripture has recently been opened to them by the Holy Spirit rather than to the Apostles at Pentecost. Third, he declared that since they considered themselves as holier than their brothers, they had excused themselves from discipline. Finally he said they produced fantasies about the end of the world and preached that the time of the Antichrist had begun. While John XXII did not mention the matter of prophecy or revelation specifically, each of the errors listed above are related to Olivi's understanding of history and his prophetic form of exegesis. Nonetheless, John XXII did not invoke Isidore's definition of a heretic in the Decretum as someone who appeals to scriptural senses other than those received by the church. ${ }^{125}$

As the persecution of the French Spirituals intensified, the Beguins were brought to the attention of the inquisition for aiding and supporting the fugitive friars in 1319. By October of 1319 three Beguins had been burned at the stake in Narbonne. ${ }^{126}$ Many more would be swept up into inquisitorial processes. The description of the errors of the Beguins provided by the infamous inquisitor Bernard Gui can be broken down into four broad categories. The first category contains various positions over the meaning of evangelical poverty and the belief that the Rule of 1223 was equivalent to the Gospel, which meant among other things that the pope could neither amend nor abolish it without becoming heretical. The second category of errors had to do with their belief that the Spirituals and Beguins burned by the inquisition were martyrs and that the inquisitors and their ecclesial superiors were the true heretics. The third category includes beliefs indicating that Francis and Olivi were prophets and that Olivi's interpretations of the Apocalypse were revealed to him by the truth of Christ in such a way as to be infallible. Finally, Gui lists various apocalyptic expectations such as the emergence of a dual antichrist, a new age when the carnal church will be replaced by a spiritual church, and of a great outpouring of the Holy Spirit to all of the elect. ${ }^{127}$

Jacques Fournier, who would become Pope Benedict XII in 1334, was also involved in suppressing the French Spirituals and the Beguins. Fournier participated in the final phase of the examination of Olivi's Lectura super Apocalypsim. ${ }^{128}$ The influence of his encounters with the Spirituals and the Beguins can be seen in his commentary on Matthew 7:15, which warned of false prophets. Fournier asked why heretics are called false prophets. His answer was that false prophets attempt to predict the future so that they will appear as if they were great before God; but their falsity is revealed when their predictions do not come true or when they contradict scripture. ${ }^{129}$ Among his list of false prophets were Joachim of Fiore and Peter Olivi. ${ }^{130}$ Whereas earlier generations were willing to wait to see if predictions come to pass, now the very act of making a prediction about the future was cause for suspicion, at least in the context of southern France from 1318 until 1370.

\section{Conclusions}

The history of Franciscan ideas about and attitudes toward prophecy from 1226 to 1326 clarifies why it became so suspicious. The suspicion was not over individuals making claims to being a prophet. Joachim of Fiore, Francis of Assisi, and Peter Olivi did not claim to be prophets. The problem emerged when they were accorded the status of prophet by their disciples. Invariably this occurred in polemical contexts of contested authority, but which side of the contest one was on mattered as to whether someone was found to be heretical or orthodox. Celano identified Francis as a prophet as a means to justify the preaching mission of the order, which had been given to the order by the Pope Gregory IX.

125 Gratian's Decretis 24.3.27.

126 (Burr 2001, p. 214).

127 For the description of the Beguines and their errors, the best text may be (Gui 1926, vol. 1, pp. 190-233).

128 (Bueno 2015, pp. 154-55).

129 Ibid. pp. 190-91.

130 Jacques Fournier, Contra haereticos libri quatuor 2.1: “Cum igitur isti duo, scilicet Joachim et P. Johannes, inter se multum discordant in supradictis, eventus etiam rerum manifeste hostendat eos falsum dixisse, cum non eveniret illu quod predixerunt in tempore vel circa tempus per eos prefixum, clarum est eos non esse prophetas Domini sed prophetas erroris." Cited from (Bueno 2015, p. 192). 
Affirming Francis' prophetic status was an affirmation of papal authority in the context of the Mendicant Controversy. Gerard of Borgo San Donnino, however, had made the mistake of going beyond what the popes had affirmed by giving Joachim of Fiore prophetic status. Since Joachim's theology posed a threat to papal authority, Gerard was condemned to imprisonment. Gerard was not, however, handed over to secular authorities for execution. There seems to have been some willingness to see if his predictions came to pass. The concerns over Augustinian traditions related to exegesis identified by Robert Lerner were raised in his case, but they would not reemerge as inquisitorial concerns for more than fifty years.

Bonaventure, on the other hand, drew upon sources approved of or written by the popes affirming Francis' status as a prophet whose teachings and mission were clearly confirmed by the miracle of the stigmata. In the Major Legend, Bonaventure claimed the Rule of 1223 was divinely inspired. He explicitly ascribed infallibility to prophetic teachings, but he saw prophecy as received through and confirmed by the ecclesial hierarchy. Bonaventure also argued for new interpretations of scripture; but he said the new interpretations could not contradict the received traditions. They could be quite novel nonetheless, such as his claim that the original sin of the church is legalism or that the principles of salvation were conceived in the uterus of God. ${ }^{131}$

Though he distinguished Francis as a prophet from the members of the order who had a prophetic habitus but were not prophets themselves, he predicted that more lay prophets were on the way. Bonaventure never suggested a papal Antichrist and over time his status grew to the point that he was recognized as a doctor of the church; however, he would have been liable to at least three of the errors Gui had ascribed to the Spirituals and Beguins. First, that the Rule of 1223 was infallible and could not be amended or abolished by the pope; second, that there would be a great outpouring of the Holy Spirit on all of the elect; and third that there would be a time of peace after the fall of the Antichrist.

Peter Olivi, on the other hand, predicted an imminent papal Antichrist. Like Gerard of San Borgo Donnino, Olivi claimed that Joachim was a prophet and tried to show how Joachim's doctrine was infallible even though it contained some errors. Since Joachim's theology had not been condemned, there was nothing heretical about his position in the context of the last two decades of the thirteenth century. Olivi went through several controversies over his understanding of usus pauper, but he was not condemned. When Olivi's doctrines were condemned by the Franciscans in 1299, prophecy was not the issue. His predictions were, however, intended to provoke resistance in the likely event that a pope would side with Franciscan leadership against the claim that usus pauper was entailed in the vow.

Just as the early Franciscans portrayed Francis as a prophet to give his way of life and doctrine a claim to infallibility, the disciples of Olivi elevated him to the status of a prophet. They directly pitted the authority of their prophet against the authority of the pope. After more than eighty executions and lesser punishments against many more, the underlying questions of the authority were left unresolved. Franciscan apologetics and polemics over prophecy were, in large part, why prophecy was seen as suspicious, but this suspicion was not due to a particular commitment to Augustinian theological traditions. In the end, the inquisition conflated papal power with orthodoxy and labelled any challenge to papal authority as heresy.

Conflicts of Interest: The author declares no conflict of interest.

\section{References}

Amorós, Leo. 1931. Series condemnationem et processum contra doctrinam et sequaces Petri Ioannis Olivi. Archivum Fransciscanum Historicum 24: 504-5.

Amorós, Leo. 1934. Aegidii Romani impugnation doctrinae Petri Ioannis Olivi an. 1311-12, nunc primum in lucem edita. AFH 9: 399-451.

131 Bonaventure, Collations on the Six Days, 16.23-25; 20.5. 
Anderson, C. Colt. 2002. A Call to Piety: St. Bonaventure's Collations on the Six Days. Quincy: Franciscan Press.

Armstrong, Regis J. 1999. The Saint, vol. 1 of Francis of Assisi: Early Documents. Edited by Regis J. Armstrong, Wayne Hellmann and William J. Short. New York: New City Press.

Armstrong, Regis J. 2000. The Founder, vol. 2 of St. Francis of Assisi: Early Documents. Edited by Regis J. Armstrong, Wayne Hellmann and William J. Short. New York: New City Press.

Augustine. 1955. De civitate Dei. Turnholt: Corpus Christianorum Latinorum, vol. 2, pp. 47-8.

Augustine of Ancona. 1985. Tractatus contra divinatores et sompniatores. In Il Tractatus Contra Divinatores et Sompniatores di Agostino d'Ancona: Introduzione e Edizione del Testo. Edited by Pierangela Giglioni. vol. 48, pp. 62-63.

Benz, Ernst. 1934. Ecclesia Spiritualis. Stuttgart: W. Kohlhammer.

Bériou, Nicole. 1990. Saint François, premier prophète de son ordre dans les sermons du XIIe siècle. Melanges de l'Ecole française de Rome-Moyen-Age 102: 544-46. [CrossRef]

Bierbaum, Max. 1920. Bettelorden und Weltgeistlichkeit an der Universität Paris. Münster: Aschendorf.

Bloomfield, Morton W. 1957. Joachim of Flora: A Critical Survey of his Canon, Teaching, Sources, Biography, and Influence. Traditio 13: 249-311. [CrossRef]

Bonaventure. 1889. De perfection. In Doctoris Seraphici S. Bonaventure Opera Omnia. Quaracchi: Collegium S. Bonaventurae.

Bonaventure. 1901. Doctoris Seraphici S. Bonaventurase Opera Omnia. Quaracchi: Collegium S. Bonaventurae.

Bonaventure. 1934-3964. S. Bonaventurae Opera Theologica Selecta. Quaracchi: Collegio S. Bonaventura.

Bonaventure. 1941. Legendae S. Francisci Assisiensis Saeculis XIII et XIV Conscriptae. Analecta Franciscana 10: 556-652.

Brady, Ignatius. 1976. St. Bonaventure's Sermons on Saint Francis. Franziskanische Studien 58: 132-37.

Bueno, Irene. 2015. Defining Heresy: Inquisition, Theology, and Papal Policy in the Time of Jacques Fournier. Brill: Leiden. Burr, David. 1993. Olivi's Peacable Kingdom. Philadelphia: University of Pennsylvania Press.

Burr, David. 2001. The Spiritual Franciscans. University Park: University of Pennsylvania Press.

Burr, David. 2014. Olivi, Fra Dolicino, and the Beast. Franciscan Studies 72: 411-32. [CrossRef]

Caesar of Heisterbach. 1910. Vita, passio et miracula S. Engelberti. Acta Sanctorum 3: 644-51.

Chenu, Marie-Dominique. 1958. Histoire et allegorie au douzième siècle. In Festgabe Joseph Lortz. Baden-Baden: Erschienen Bei Bruno Grimm.

Congar, Yves. 1958. Le sens de l'economie salutary dans la théologie de St. Thomas d'Aquin. In Festgabe Joseph Lortz. Baden-Baden: Erschienen Bei Bruno Grimm.

Congar, Yves. 1961. Aspects Ecclésiologiques de la Querelle entre Mendiants et Séculiers dans la Seconde Moitié du XIIIe Siècle et le Début du XIVe. Archives d'Histoire Doctrinale et Litteraire du Moyen Age 36: 35-151.

Daniel, E. Randolph. 1992. Joachim of Fiore: Patterns of History in the Apocalypse. In The Apocalypse in the Middle Ages. Edited by Richard K. Emmerson and Bernard McGinn. Ithaca: Cornell University Press.

De Adam, Salimbene. 1986. The Chronicle of Salimbene de Adam. Translated by Joseph L. Baird. Binghamton: Medieval \& Renaissance Texts \& Studies.

De Lubac, Henri. 1978. La Posterite Spirituelle de Joachim de Flore. Paris: Lethielleux.

Translated by Jose De Vinck. 1970, Collations on the Six Days. In The Works of Bonaventure. Paterson: St. Anthony Guild Press.

Dempf, Alois. 1929. Sacrum Imperium. Munich: Oldenbourg.

Denifle, Heinrich. 1885. Das Evangelium aeternum und die Commission zu Anagni. Archiv für Literatur und Kirchen Geschicte des Mittelalters 1: 49-98.

Emery, Richard. 1954. The Second Council of Lyons and the Mendicant Orders. Catholic Historical Review 39: 257-71.

Eubel, Konrad, ed. 1898. Bullarium Franciscanum 5. Rome: Typis Sacrae Congregationis De Propaganda Fide.

Faral, Edmond. 1950-1951. "Les <<Responsiones >> De Guilliame De St. Amour". Archives D'Histoire Doctrinale et Littéraire du Moyen Age 25-26: 337-94.

Friedberg, Emil. 1879-1881. Corpus Iuris Canonici. Leipzig: Bernhard Tauchnitz.

Gerhoh of Reichersberg. 1894. "De quarta vigilia noctis". Monumenta Germaniae Historica 3: 503-25.

Grundmann, Herbert. 1966. Studien über Joachim von Fiore. Leipzig: B.G. Teubner. First published 1927.

Gui, Bernard. 1926. Manuel de l'Inquisiteur. Edited by Guillaume Mollat. Paris: Champion. 
Horan, Daniel P. 2014. Bonaventure's Theology of Prophecy in the Legenda Major: Sources and Interpretation. Antonianum 89: 43-78.

Iglesias, F. 1988. Prophetic Originality of St. Francis. Greyfriars Review 2: 45-90.

Innocent, III. 1844-1864. Cum ex Iniuncto. In Patrologiæ Cursus Completus: Sive Bibliotheca Universalis, Integra, Uniformis, Commoda, Oeconomica, Omnium SS. Patrum, Doctorum, Scriptorumque Ecclesiasticorum. Series Latina. Edited by Jacques Paul Migne. Paris.

Isidore of Seville. 1981. Etymologies. In Auteur latins du Moyen Age. Paris: Les Belles Lettres.

Joachim. 1965. Psalterium Decem Chordarum. Frankfurt: Minerva. First published 1527.

Joachim of Fiore. 1979. Apocalyptic Spirituality. Translated by Bernard McGinn. New York: Paulist Press.

Joachim of Fiore. 1983. Book of Concord. In Liber de Concordie Novi ac Veteris Testamenti. Edited by E. Randolph Daniel. Philadelphia: The American Philosophical Society.

Joachim of Fiore. 1983. Liber de Concordie Novi ac Veteris Testamenti. Edited by E. Randolph Daniel. Philadelphia: Transactions of the American Philosophical Society.

Lambert, Malcolm D. 1998. Franciscan Poverty: The Doctrine of the Absolute Poverty of Christ and the Apostles in the Franciscan Order 1210-1323. St. Bonaventure: The Franciscan Institute.

Lerner, Robert. 1976. Refreshment of the Saints: The Time after the Antichrist as a station of Earthly Progress in Medieval Thought. Traditio 32: 97-144. [CrossRef]

Lerner, Robert. 1992. Ecstatic Dissent. Speculum 67: 47-8. [CrossRef]

Lerner, Robert. 1994. Historical Introduction. In Johannes de Rupescissa, Liber Secretorum Eventuum. Edited by Robert E. Lerner and Christine Morerod-Fattebert. Fribourg: Éditions Universitaires Fribourg Suisse.

Madigan, Kevin. 2003. Olivi and the Interpretation of Matthew in the High Middle Ages. Notre Dame: Notre Dame Press.

Markus, Robert A. 1970. Saeculum: History and Society in the Theology of St Augustine. Cambridge: Cambridge University Press.

McGinn, Bernard. 1979. Visions of the End: Apocalyptic Traditions in the Middle Ages. New York: Columbia University Press.

McGinn, Bernard. 1985. The Calabrian Abbot: Joachim of Fiore in the History of Western Thought. New York: Macmillan Publishing Company.

McGinn, Bernard. 1999. Antichrist: Two Thousand Years of the Human Fascination with Evil. New York: Columbia University Press.

Meagher, Luanne. The Fathers of the Church: St. Augustine. New York: CIMA Publishing.

Monti, Dominic. 1994. Introduction. In St. Bonaventure's Writings Concerning the Franciscan Order. Edited by George Marcil. Translated by Dominic Monti. St. Bonaventure: Franciscan Institute.

Monti, Dominic. 2010. 'Deservedly approved by the Roman Church': The context for Papal Recognition of Francis's forma vitae. In The Rule of the Friars Minor, 1209-2009 Historical Perspectives, Lived Realities. St. Bonaventure: Franciscan Institute.

Olivi, Peter of John. 1997. Super Isaiam, Super titulum. In Peter of John Olivi on the Bible: Principia Quinque in Sacram Scripturam, Postilla in Iaiam et in 1 ad Corinthios. Edited by David Flood and Gedeon Gál. St. Bonaventure: Franciscan Institute Publications.

Olivi, Peter of John. 2017. Commentary on the Apocalypse. Warren Lewis, trans. and ed. St. Bonaventure: Franciscan Institute Publications.

Pásztòr, Edith. 1987. St. Francis, Cardinal Hugolino, and the 'Franciscan Question'. Greyfriars Review 1: 1-29.

Rambow, George. 2017. The Function and Spirituality of Bonaventure's "Treatise" on the Miracles of St. Francis. Franciscan Studies 75: 337-41. [CrossRef]

Ratzinger, Joseph. 1971. The Theology of History in St. Bonaventure. Translated by Zachary Hayes. Chicago: Franciscan Herald Press.

Reeves, Marjorie. 1969. The Influence of Prophecy in the Latter Middle Ages. Oxford: Clarendon Press.

Renna, Thomas. 2002. St. Francis as Prophet in Celano and St. Bonaventure. Michigan Academician 33: 321-32.

Short, William. 2010. Revising the earlier Rule: Carlo Paolazzi and the work of Kajetan Esser. In The Rule of the Friars Minor, 1209-2009 Historical Perspectives, Lived Realities. Edited by Daria Mitchell. St. Bonaventure: Franciscan Institute.

Smalley, Beryl. 1964. The Study of the Bible in the Middle Ages. Notre Dame: University of Notre Dame Press.

Van Engen, John. 1983. Rupert of Deutz. Berkley: University of California Press. 
Vauchez, Andre. 1968. Les stigmates de saint François et leurs detracteurs dans les dernier siècles du moyen âge. Mélanges d'Archéologie et d'Histoire 80: 601-12. [CrossRef]

Wadding, Luke. 1731-1745. Annales Minorum, 2nd ed. Rome: Ioannis Petri Collinii.

William of St. Amour. 1632. Opera Omnia. Constance: unknown publisher.

William of St. Amour. 1690. De Periculis Novissimi Temporis. In Fasciculus Rerum Extendarum. Edited by E. Brown and O. Gratius. London: unknown publisher. 